\title{
Ceasing Vitamin D Replacement in Infants with Premature Closure of Front Fontanelle: True or False?
} Ön Fontaneli Erken Kapanan Bebeklerde D Vitamini
Replasmanının Durdurulması: Doğru Mu? Yanlış Mı? (D) Tolga Ünüvar ${ }^{1}$, (1) Türkan Uygur Şahin², (1) Erdal Adal ${ }^{3}$

${ }^{1}$ Aydın Adnan Menderes University Faculty of Medicine, Department of Pediatric Endocrinology, Aydın, Turkey 2University of Health Sciences Turkey, Kanuni Sultan Süleyman Training and Research Hospital, Clinic of Pediatrics, İstanbul, Turkey

${ }^{3}$ Bağcılar Medipol Mega University Hospital, Clinic of Pediatric Endocrinology, İstanbul, Turkey

Keywords

Vitamin D, anterior fontanelle closure, child

Anahtar Kelimeler

D vitamini, ön fontanel kapanması, çocuk

Received/Geliş Tarihi : 07.11.2020

Accepted/Kabul Tarihi : 15.11.2020

doi:10.4274/meandros.galenos.2020.37268

Address for Correspondence/Yazışma Adresi: Tolga Ünüvar Assoc. Prof. Dr. Aydın Adnan Menderes University Faculty of Medicine, Department of Pediatric Endocrinology, Aydın, Turkey

Phone : +90 5057284111

E-mail : tunuvar@gmail.com

ORCID ID: orcid.org/0000-0002-5517-5030

(C) Meandros Medical and Dental Journal, Published by Galenos Publishing House.

This is article distributed under the terms of the Creative Commons Attribution NonCommercial 4.0 International Licence (CC BY-NC 4.0).

\begin{abstract}
Objective: The purpose of this study was to determine whether fontanelle closure in neonatal and early infantry periods was related to vitamin D levels and the prophylaxis of vitamin D intake. Moreover, our analysis was structured in a retrospective, controlled manner to evaluate our hypothesis.

Materials and Methods: We considered 50 individuals who applied to our child endocrinology polyclinic with infants suffering from premature anterior closure. Further, 35 healthy infants of the same age and gender having open anterior fontanelles were taken as the control group.

Results: The serum vitamin D level was found to be lower, and the parathormone level was significantly higher in the group with premature closure of the anterior fontanelle. In addition, there was a significant difference in serum calcium, alkaline phosphatase and parathormone levels in patients who had ceased vitamin D support compared with regular vitamin D users. While there was no significant difference in serum vitamin D levels, the level was lower in patients who had withdrawn vitamin D support.

Conclusion: In our study, many infants have much lower vitamin D levels than normal levels, even though their anterior fontanelle is prematurely closed. Thus, physicians and other health workers are also warned of the continuity of vitamin D prophylaxis and that it is wrong to cease vitamin D support for reasons such as the premature closing of the anterior fontanelle.
\end{abstract}

Öz

Amaç: Biz çalışmamızda yenidoğan ve erken süt çocukluğu döneminde fontanel kapanmasının D vitamini düzeyi ve aldığı D vitamini profilaksisinin miktarı ile ilişkili olup olmadığını araştırmak istedik.

Gereç ve Yöntemler: Çocuk endokrin polikliniğimize ön fontaneli 6. aydan erken kapanma şikayetiyle başvuran veya rutin muayene esnasında ön fontanelin 6 . aydan önce kapandığı saptanan 50 hastanın çalışmaya alınması planlandı. Aynı yaş ve cinsiyetten ön fontaneli açık 35 sağlıklı çocuk kontrol grubu olarak alındı.

Bulgular: Çalışmamızda, ön fontaneli erken kapanan grupta serum D vitamini düzeyi daha düşük saptanmasına karşın kontrol grubu ile arasında anlamlı bir fark 
saptanamadı. Serum parathormon düzeyi ise fontaneli erken kapanan hasta grubunda anlamlı olarak yükselmişti. D vitamini desteği kesilen hastalar ile düzenli D vitamini desteği alan hastalar karşılaştıııldığında serum kalsiyum, alkalen fosfataz ve parathormon düzeyleri arasında anlamlı fark saptandı. Serum D vitamini düzeyleri arasındaki fark anlamlı olmasa da D vitamini desteği kesilen hastalarda daha düşüktü.

Sonuç: Çalışmamızda da gördüğümüz gibi ön fontaneli erken kapansa dahi vitamin D düzeyi normal hatta normalin altında birçok infant bulunmaktadır. Bu nedenle hem hekimlerin hem de diğer sağlık çalışanlarının D vitamini profilaksisinin devamlılı̆ı konusunda uyarılması ve ön fontanel erken kapanması gibi sebeplerle D vitamini desteğinin kesilmesinin yanlış olduğu vurgulanmalıdır.

\section{Introduction}

Nutritional rickets and vitamin D deficiency are two common serious yet preventable problems, and they are frequently treated by ceasing the support of vitamin $\mathrm{D}$ due to associating the premature closure of anterior fontanelle in neonatal and infantry periods with vitamin D excess. As the deficiency of vitamin $D$ is known to delay the closure of anterior fontanelle, infants with premature closure of anterior fontanelle are thought to have vitamin D excess and the cease of vitamin $D$ prophylaxis is the first thing that comes to mind. This is a treatment which increases the risks of vitamin $\mathrm{D}$ deficiency and rickets in neonates and infants. When we had an emergency patient who applied to us with the clinical findings of hypocalsemic convulsion and rickets due to early cease of vitamin $D$ support by the infant's doctor on the grounds that the infant had premature closure of anterior fontanelle, we felt the need of carrying out a study on the issue.

Vitamin $D$ is a prohormone that is closely associated with the calcium phosphorus metabolism in our body. Calcium absorption from gastrointestinal system and its mineralization in the bone with phosphorus can only occur in the presence of vitamin D. In the study, vitamin $D$ was found in various types of cells among which the immune system, skin, pancreas and the bone are the foremost (1-4).

As stated by Hollick (1), 25-hydroxyvitamin D $[25(\mathrm{OH}) \mathrm{D}]$ is the best indicator of the nutritional state. When serum 25(OH)D level is below $20 \mathrm{ng} / \mathrm{mL}$, this is called vitamin $D$ deficiency, when it is between 20-36 ng/mL, this is called vitamin $D$ insuffiency. If serum vitamin $D$ is between $10-20 \mathrm{ng} / \mathrm{mL}$, this is low level deficiency; between $5-10 \mathrm{ng} / \mathrm{mL}$, this is medium level deficiency; $<5 \mathrm{ng} / \mathrm{mL}$, this is serious deficiency $(5,6)$. In the published Endocrine Society's Practice Guidelines on vitamin $D$, vitamin $D$ deficiency was defined as a $25(\mathrm{OH}) \mathrm{D}<20 \mathrm{ng} / \mathrm{mL}$, insufficiency as 21 $29 \mathrm{ng} / \mathrm{mL}$ and sufficiency as at least $30 \mathrm{ng} / \mathrm{mL}$ for maximum musculoskeletal health (7). The vitamin D deficiency seen in neonatal and infantry periods is closely related to pregnancy and postpartum vitamin D levels. Sufficient 25(OH)D level shall be between 40 $60 \mathrm{ng} / \mathrm{mL}$, which corresponds to a daily intake of 4,000 IU vitamin D (1). Classical rickets symptoms due to vitamin $\mathrm{D}$ deficiency is more common in kids between 6 months old- 2.5 years old. It may be asymptomatic in early periods; or it may be accompanied by a sensitivity in skeleton-muscle system, craniotabes, widening in wrists, breaks, frontal bossing, delay of anterior fontanelle, Harrison's Groove, rachitic rosary, short stature and growth retardation. There may be teething retardation or defects in tooth enamel $(8,9)$.

Anterior fontanelle has a significant role in the clinical evaluation of infants. In their $1^{\text {st }}$ postnatal days, the size of a normal anterior fontanelle is between $0.6 \mathrm{~cm}-3.6 \mathrm{~cm}$ (2.1 cm on average) (10). When the premature infants reach their normal birth terms, the size of their fontanelles show parallelism with term infants. The anterior fontanelle, which is detected to close in 13.8 months on average, may show widening in the first months of life (11). Many studies were made on their sizes and closure times. In $1 \%$, anterior fontanelle closure was seen in the first 3 months; in 38\%, closure was seen within 12 months; and $96 \%$ was seen to close by 24 months. While the anterior fontanelle closed earlier in boys than girls, there wasn't any pre-estimation about the size and closure time of the fontanelle (12). It was also found in these studies that; anterior fontanelle closure had no significant relationship with head circumference and bone age, anterior fontanelle gap didn't reflect the infant's calcium level, either (13).

To get protected from rickets and vitamin D deficiency, all neonates feeding on breast milk shall be started with a support of 400 units of vitamin D since the first days of life. This support shall be continued until the baby starts to take at least 1 litre of formula milk containing vitamin $D(14,15)$. 
We wanted to inquire whether fontanelle closure in neonatal and early infantry periods was related to vitamin $D$ level and the prophylaxis amount of the vitamin D intake, and even to show that infants with premature closure of anterior fontanelle could also have vitamin $D$ deficiency.

\section{Materials and Methods}

We planned our study in a retrospective, controlled way to evaluate our hypothesis. The study was approved by Non-invasive Clinical Research Ethics Committee of Aydın Adnan Menderes University Faculty of Medicine (protocol no: 2020-227). Before the study, retrospective procedures were explained and all subjects gave consent for study. For our study, we considered 50 patients who applied to our pediatric endocrinology polyclinic with the suffering of premature anterior closure (closure before the $6^{\text {th }}$ month) or whose anterior fontanelles were found to have closed before the $6^{\text {th }}$ month. Patients with accompanying syndromic hypothyroid, hypoparathyroid, macrocephaly or hydrocephaly were excluded from the study. Thirty five healthy infants of the same age and gender who had open anterior fontanelles were taken as the control group. Average age of the patients whose anterior fontanelles closed prematurely was found to be $2.75 \pm 1.52$ months old. On the other hand, average age of the infants in the control groups was $3.04 \pm 1.51$ months old $(p=0.398)$. While $52 \%$ of the group with premature anterior fontanelle closure consisted of male patients, the rate of males in the control group was found to be $54.3 \%$ $(p=0.835)$. All patients included in the study were terms with respect to their gestational age, premature ones were excluded. Gestational weeks, delivery ways, birth weights and head circumferences of the patients, and their weights and head circumferences on the date of application were all recorded. The vitamin D dose they had been using on application, mother's vitamin $\mathrm{D}$ intake background during pregnancy and the infant's nutritional background were noted down. Serum pre-prandial calcium, phosphorus, alkaline phosphates, vitamin D and parathormone levels of all patients were noted from the patient's files.

\section{Statistical Analysis}

Statistical analysis of data were performed with Statistical Package for Social Science 17.0 packaged software. Definitive and frequency analysis were performed. Distribution and homogeneity of the data were assessed with Sample K-S and One-Way ANOVA tests. Chi-square, parametric independent samples, t-test and nonparametric Mann-Whitney $U$ tests were used to compare the two groups.

\section{Results}

Twenty eight of the patients with premature closure of anterior fontanelle were delivered by regular spontaneous vaginal way while the remaining 22 were delivered by caesarean operation. On the other hand; 21 of the patients in control group were delivered by regular spontaneous way while the 14 were delivered by caesarean operation $(p=0.713)$. While the average birth weights of the patients with closed anterior fontanelles were between $3280 \pm 360.3$ grams, the ones in the control group had an average birth weight between $3115 \pm 452.1$ grams $(p=0.327)$. While the infants who had premature closure of anterior fontanelle had an average head circumference of $35.8 \pm 0.71 \mathrm{~cm}$ at birth, average head circumference of the control group was measured as $36.6 \pm 0.90 \mathrm{~cm}$, which was considered to be statistically significant $(p<0.001)$. However; there was no significant statistical difference between the group with premature closure of anterior fontanelle and the control group with respect to the head circumference on the date of application $(40.2 \pm 2.1 \mathrm{~cm}$ and $41.1 \pm 2.63$ $\mathrm{cm}$ respectively) ( $\mathrm{p}=0.272)$. While 19 of the infants with premature closure of anterior fontanelle were feeding on breast milk only, 31 of them were taking formula milk support. On the other hand; the number of infants feeding on breast milk only was 17 whereas the number of the ones also taking formula milk support was $18(p=0.481)$. There was no significant statistical difference between the two groups with respect to average serum calcium, phosphorus, alkaline phosphatase and vitamin D levels. But serum parathormone level was significantly high in the patient group with premature closure of anterior fontanelle $(p=0.001)$. Comparison of the laboratory findings of the two groups are given in Table 1.

Twenty six of the infants who had premature closure of anterior fontanelle had been ceased of vitamin D support upon doctor's advice. On the other hand, the patients in the control group were using three drops of vitamin D daily. There was a statistically 
significant difference between the two groups with respect to the vitamin $D$ usage background $(p<0.001)$. When the patients who had been ceased of vitamin D support were compared with the regular vitamin $D$ takers in the control group, a significant difference was observed considering serum calcium, alkaline phosphatase and parathormone levels ( $p=0.016$ and $p=0.03$ and $p=0.0001$ respectively). Even though there was no significant difference considering serum vitamin D levels, the level was lower in the patients who had been ceased of vitamin D support $(p=0.076)$ (Table 2).

While 30 of the mothers who had infants with premature closure of anterior fontanelle reported to have taken vitamin $D$ support during their pregnancy, this number was 15 is the control group $(p=0.119)$. Birth weight and head circumference of the infants in the control group whose mothers had taken vitamin D support were significantly higher than the babies in the control group whose mothers hadn't taken vitamin $D$ support ( $p=0.04$ and 0.026 respectively). Even though the infants whose mothers had taken vitamin D support during their pregnancy had higher levels of serum vitamin $D$ and calcium levels, there was no significant difference between them $(p=0.061$ and 0.804 respectively) (Table 3 ).

\section{Discussion}

Nutritional rickets and vitamin D deficiency are common yet preventable problems today in our country as all around the world. World Health Organization publishes regularly updated leaflets emphasizing the significance and necessity of vitamin D support in neonates and adolescents $(14,15)$. Despite that; there is a common treatment of the cease of vitamin $D$ support due to associating the premature closure of anterior fontanelle in neonates with vitamin $D$ excess. This treatment increases the risk of vitamin $\mathrm{D}$ deficiency and rickets in neonates and infants.

\begin{tabular}{|l|l|l|l|}
\hline Table 1. Comparison of the average laboratory values of the two groups & P* \\
\hline Average & $\begin{array}{l}\text { Patients with premature closure } \\
\text { of anterior fontanelle }\end{array}$ & Control group & - \\
\hline $\mathbf{n}$ & 50 & 35 & 0.398 \\
\hline Age (months) & $2.75 \pm 1.52$ & $3.04 \pm 1.51$ & 0.519 \\
\hline Serum calcium level (mg/dL) & $9.31 \pm 0.87$ & $9.28 \pm 0.45$ & 0.227 \\
\hline Serum phosphorus level (mg/dL) & $5.10 \pm 0.61$ & $4.93 \pm 0.69$ & 0.097 \\
\hline Serum alkaline phosphatase Level (u/L) & $241 \pm 67.7$ & $217 \pm 56.9$ & 0.304 \\
\hline Serum vitamin D level $(\mathrm{ng} / \mathrm{mL})$ & $24.7 \pm 11.5$ & $27.7 \pm 14.01$ & 0.001 \\
\hline Serum parathormone level $(\mathbf{p g} / \mathrm{mL})$ & $29.85 \pm 17.3$ & \\
\hline *Mann-Whitney U test was used for serum vitamin D and calcium levels and t-test was used for the other data, p<0.05 was considered to be significant \\
\hline
\end{tabular}

Table 2. Comparison of the patients who had been ceased of vitamin D support upon doctor's advice with the regular vitamin $\mathrm{D}$ takers in the control group

\begin{tabular}{|l|l|l|l|}
\hline Average & $\begin{array}{l}\text { Patients who had been ceased of vitamin } \\
\text { D support }\end{array}$ & $\begin{array}{l}\text { Control group taking } \\
\text { vitamin D support }\end{array}$ & p* \\
\hline $\mathbf{n}$ & 26 & 35 & - \\
\hline Age (months) & $2.65 \pm 1.17$ & $3.04 \pm 1.51$ & 0.286 \\
\hline Serum calcium level $(\mathrm{mg} / \mathrm{dL})$ & $8.97 \pm 0.78$ & $9.28 \pm 0.45$ & 0.016 \\
\hline Serum phosphorus level (mg/dL) & $5.04 \pm 0.66$ & $4.83 \pm 0.86$ & 0.303 \\
\hline $\begin{array}{l}\text { Serum alkaline phosphatase level } \\
\text { (u/L) }\end{array}$ & $263 \pm 61$ & $217 \pm 56.9$ & 0.003 \\
\hline Serum vitamin D level $(\mathrm{ng} / \mathrm{mL})$ & $21.45 \pm 9.89$ & $27.7 \pm 14.01$ & 0.076 \\
\hline Serum parathormone level $(\mathrm{pg} / \mathrm{mL})$ & $51.27 \pm 19$ & $29.85 \pm 17.3$ & 0.001 \\
\hline *Mann-Whitney U test was used for serum vitamin D and calcium levels and t-test was used for the other data, p<0.05 was considered to be significant \\
\hline
\end{tabular}


Though in our study, serum vitamin D level was observed to be lower in the group with premature closure of anterior fontanelle, there was no significant difference from the control group. Wang J et al. (13) found in their study that, serum calcium and vitamin $D$ levels of infants did not reflect the size of fontanelles and emphasized that closure of anterior fontanelle was independent from serum vitamin $D$ and calcium levels. Thus; it was not an appropriate approach to cease vitamin $D$ support in infants on the grounds that they had premature closure of anterior fontanelle without looking at their serum vitamin D levels. As can be seen in our study, patients who had premature closure of anterior fontanelle did not have high vitamin $D$ levels, this level could even be lower. When the doctors also cease vitamin D support in countries like Turkey where vitamin $D$ deficiency is widely seen, nutritional rickets incidence rate gets even higher. Apart from these, there was no significant statistical difference between the two groups considering calcium, phosphorus and alkaline phosphatase levels. However; patients with premature closure of anterior fontanelle had significantly higher level of serum parathormone levels compared to the control group $(p=0.001)$. When infants with already low vitamin $D$ level at the limits were ceased of vitamin D support, their serum parathormone levels increased. Even though the organism tries to warn us at the early stage by increasing parathormone levels that it is wrong to cease vitamin D support, we usually ignore this warning.
In our study, 26 of the infants with premature closure of anterior fontanelle had been ceased of vitamin D upon doctor's advice. On the other hand; all patients in control group were taking three drops of (400 units) vitamin D daily. There was a statistically significant difference between the two groups considering the vitamin $D$ intake background $(p<0.001)$. This difference, which we presumed while planning this study, further increases the nutritional rickets incidence in countries where there is a high rate of vitamin $D$ deficiency. As no similar studies are found in literature, we wanted to emphasize this issue to raise awareness both in patients and in doctors.

While infants with premature closure of anterior fontanelle had $35.8 \pm 0.71 \mathrm{~cm}$ head circumference at birth, members of the control group were measured to have a head circumference of $36.6 \pm 0.90 \mathrm{~cm}$ and the difference was considered to be statistically significant $(p<0.001)$. The birth head circumference of the infants with premature closure of anterior fontanelle was significantly smaller than that of the control group, and this brought the following question in minds; "Do neonates with small birth head circumference are riskier considering the possibility of premature closure of anterior fontanelle?" We need further studies on this issue.

While serum calcium levels of the patients who were ceased of vitamin D support were significantly lower than the regular vitamin $D$ takers in the control group; their serum alkaline phosphatase and serum parathormone levels were significantly higher than

Table 3. Comparison of the infants whose mothers had taken vitamin D support during their pregnancy with the control group with respect to laboratory and anthropometric measurements

\begin{tabular}{|c|c|c|c|}
\hline Average & $\begin{array}{l}\text { Infants whose mothers had taken } \\
\text { vitamin D support during their } \\
\text { pregnancy }\end{array}$ & $\begin{array}{l}\text { Control group who had not } \\
\text { taken vitamin D support } \\
\text { during their pregnancy }\end{array}$ & p* \\
\hline $\mathbf{n}$ & 30 & 20 & - \\
\hline Age (months) & $3.01 \pm 1.53$ & $3.00 \pm 1.61$ & 0.971 \\
\hline Serum calcium level (mg/dL) & $9.34 \pm 0.75$ & $9.23 \pm 0.50$ & 0.804 \\
\hline Birth weight (gr) & $3.35 \pm 355.38$ & $3.02 \pm 408.89$ & 0.004 \\
\hline Birth head circumference $(\mathrm{cm})$ & $36.11 \pm 0.71$ & $36.61 \pm 0.77$ & 0.026 \\
\hline Serum phosphorus level (mg/dL) & $5.64 \pm 0.93$ & $4.75 \pm 0.85$ & 0.001 \\
\hline Serum alkaline phosphatase level (u/L) & $234 \pm 71.75$ & $217 \pm 52.95$ & 0.370 \\
\hline Serum vitamin D level $(\mathrm{ng} / \mathrm{mL}$ ) & $28.58 \pm 10.63$ & $22.89 \pm 12.66$ & 0.061 \\
\hline Serum parathormone level $(\mathrm{pg} / \mathrm{mL})$ & $39.47 \pm 15.99$ & $31.94 \pm 19.37$ & 0.141 \\
\hline
\end{tabular}


those of the control group $(p=0.016$ and $p=0.03$ and $p=0.0001$ respectively). Though there was no significant difference between the two groups considering serum vitamin D levels, the level was lower in patients who had been ceased of vitamin $D$ support $(p=0.076)$. When oral 400 units of vitamin D replacement was given regularly, serum level increased above $20 \mathrm{ng} / \mathrm{mL}$. The ones with darker skin, winter babies, veiled mothers' babies had higher daily need $(16,17)$. In literature, no vitamin D intoxication was seen with 400 units vitamin D prophylaxis, even 1427 units/day vitamin D replacement did not cause any intoxication (18). In our study, the group who were younger than 3 months old and had been ceased of vitamin D support developed vitamin D deficiency in such a short time and metabolic changes came up to compensate for this state. This shows how wrong it is to cease vitamin $D$ support due to premature closure of anterior fontanelle or the risk of intoxication.

$62 \%$ of the infants $(n=32)$ in the group with premature closure of anterior fontanelle were feeding on formula milk. Vitamin D level of the infants feeding on formula milk was found to be higher than the vitamin $D$ level of the infants feeding on breast milk only $(p=0.039)$. This was directly related to the insufficiency of vitamin D amount in mother's milk (19).

Birth weights and head circumference of the neonates whose mothers had taken vitamin $D$ support during their pregnancy were significantly higher than those of the neonates whose mothers had not taken vitamin D support during their pregnancy. Though serum $D$ vitamin and calcium levels of the infants whose mothers had taken vitamin D support during their pregnancy were higher than the control group, there was no significant difference between them. In their study, Kalra et al. (20) compared the infants whose mothers had received 1.500 units of vitamin $D$ in second trimester and 3.000 units of vitamin $D$ in second and third trimesters with the infants whose mothers had taken no vitamin D support during their pregnancy. Anterior fontanelle sizes of the infants whose mothers had received vitamin $D$ support were found to have smaller size of anterior fontanelle. But, no infants with premature closure of anterior fontanelle were reported. In our study, 30 of the mothers of the infants with premature closure of anterior fontanelle had received vitamin $D$ support during their pregnancy and in parallel to the studies of Kalra et al. (20), they had higher birth weight and larger head circumference. As Kalra et al. (20) found that these infants had smaller anterior fontanelles, and we found in our study that 30 of the mothers of the infants with premature closure of anterior fontanelle had received vitamin D support during their pregnancy, the following question comes to minds; "Do vitamin intake during pregnancy cause premature closure of anterior fontanelle?" Though we need more patient covering studies on the issue, as in our study the average serum vitamin D level of the infants whose mothers were in this group was below $30 \mathrm{ng} / \mathrm{mL}$, and Wang $\mathrm{J}$ et al. (13) showed that there was no relation between vitamin $D$ replacements and anterior fontanelle size; we move away from this hypothesis.

Another frequently faced problem in our country which we did not dealt with in this study is that, patients whose families think that their children have growth retardation, bone weakness, teething retardation have these children take overdose vitamin D support upon a doctor's or another health officer's advise. These patients have normal level of vitamin $D$ and they don't need high dose prophylaxis.

\section{Results}

As a result we may face vitamin $D$ intoxication or nephrocalcinosis and these may reach up to health threatening levels. Here we wanted to emphasize that, states like growth retardation, teething retardation or bone weakness did not indicate that high dose of vitamin $D$ support was required without the need of measuring vitamin D levels first. Again further controlled studies covering more patient groups are needed.

\section{Conclusion}

Vitamin D support shall be received in an appropriate dose and for an appropriate period in order to prevent a significant health problem which is vitamin $D$ deficiency and rickets. As also shown in our study, there are many infants who have normal even lower than normal vitamin D levels even though their anterior fontanelle gets closed prematurely. Thus; both the doctors and other health personnel shall be warned about the continuity of vitamin $D$ 
prophylaxis and that it is wrong to cease vitamin D support for reasons such as premature closure of anterior fontanelle.

Ethics

Ethics Committee Approval: The study was approved by Non-invasive Clinical Research Ethics Committee of Aydın Adnan Menderes University Faculty of Medicine (protocol no: 2020-227).

Informed Consent: Before the study, retrospective procedures were explained and all subjects gave consent for study.

Peer-review: Externally peer-reviewed.

\section{Authorship Contributions}

Concept: T.Ü., T.U.Ş., E.A., Design: T.Ü., T.U.Ş., E.A., Supervision: T.Ü., T.U.Ş., E.A., Fundings: T.Ü., Materials: T.U.Ş., Data Collection or Processing: T.Ü., Analysis or Interpretation: T.Ü., T.U.Ş., E.A., Literature Search: T.Ü., Writing: T.Ü., T.U.Ş., Critical Review: T.Ü., T.U.Ş., E.A.

Conflict of Interest: No conflict of interest was declared by the authors.

Financial Disclosure: The authors declared that this study received no financial support.

\section{References}

1. Holick MF. The vitamin D deficiency pandemic: Approaches for diagnosis, treatment and prevention. Rev Endocr Metab Disord 2017; 18: 153-65.

2. Christakos S, Dhawan P, Liu Y, Peng X, Porta A. New insights into the mechanisms of vitamin D action. J Cell Biochem 2003; 88: 695-705.

3. Plotkin H, Lifshitz F. Rickets and Osteoporosis. In: Liftshitz F, editor. Pediatric Endocrinology. 5th ed. New York: Informa Healthcare; 2007: 531-4.

4. Unuvar T, Büyükgebiz A. Nutritional rickets and vitamin D deficiency in infants, children and adolescents. Pediatr Endocrinol Rev 2010; 3: 283-91.

5. Gordon CM, De Peter KC, Feldman HA, Grace E, Emans SJ. Prevalence of vitamin $D$ deficiency among healthy adolescents. Arch Pediatr Adolesc Med 2004; 158: 531-7.

6. Abrams SA, Griffin IJ, Hawthorne KM, Gunn SK, Gundberg CM, Carpenter TO. Relationships among vitamin D levels, parathyroid hormone, and calcium absorption in young adolescents. J Clin Endocrinol Metab 2005; 90: 5576-81.

7. Holick MF, Binkley NC, Bischoff-Ferrari HA, Gordon CM, Hanley DA, Heaney RP, et al. Evaluation, treatment, and prevention of vitamin D deficiency: an Endocrine Society clinical practice guideline. J Clin Endocrinol Metab 2011; 96: 1911-30.

8. Misra M, Pacaud D, Petryk A, Collett-Solberg PF, Kappy M. Vitamin $D$ deficiency in children and its management: review of current knowledge and recommendations. Pediatrics 2008; 122: 398-417.

9. Holick MF. Vitamin D deficiency. N Engl J Med 2007; 357: 266-81.

10. Popich GA, Smith DW. Fontanelles: range of normal size. J Pediatr 1972; 80: 749-52.

11. Kliegman RM. The newborn infant. In: Behrman RE, Kliegman RM, Arvin AM, Nelson WE, editors. Nelson Textbook of pediatrics. 15th ed. Phidelphia: Saunders; 1996: 433-40.

12. Duc G, Largo $\mathrm{RH}$. Anterior fontanelle: size and closure in term and preterm infants. Pediatrics 1986; 78: 904-8.

13. Wang J, Li H, He Q, Ren C. Effects of calcium and vitamin D supplemetation on bone specific alkaline during pregnancy lactation and infant. Wei Sheng Yan Jiu 2009; 38: 193-5.

14. Gartner LM, Greer FR. Prevention of rickets and vitamin D deficiency: new guidelines for vitamin D intake. Pediatrics 2003; 111: 908-10.

15. Wagner $\mathrm{CL}$, Greer FR. Prevention of rickets and vitamin D deficiency in infants, children, and adolescents. Pediatrics 2008; 122: 1142-52.

16. Hollis BW. Circulating 25-hydroxyvitamin D levels indicative of vitamin D sufficiency: implications for establishing a new effective dietary intake recommendation for vitamin D. J Nutr 2005; 135: 317-22.

17. Hatun Ş, İslam Ö, Cizmecioğlu F, Kara B, Babaoglu K. Subclinical Vitamin D Deficiency Is Increased in Adolescent Girls Who Wear Concealing Clothing. J Nutr 2005; 135: 218-22

18. Zeghoud F, Vervel C, Guillozo H, Walrant-Debray O, Boutignon $H$, Garabédian M. Subclinical vitamin D deficiency in neonates: definition and response to vitamin D supplements. Am J Clin Nutr 1997; 65: 771-8.

19. Abdul - Razzak KK, Ajlony MJ, Khoursheed AM, Obeidat BA. Vitamin $D$ deficiency among healthy infants and toddlers: $A$ prospective study from Irbid, Jordan. Pediatr Int 2011; 53: 83945.

20. Kalra P, Das V, Agarwal A, Kumar M, Ramesh V, Bhatia E, et al. Effect of vitamin $D$ supplementation during pregnancy on neonatal mineral homeostasis and anthropometry of the newborn and infant. Br J Nutr 2012; 3: 1-7. 